\title{
Ягоды: химический состав, антиоксидантная активность Влияние потребления ягод на здоровье человека
}

А. Я. Яшин, К. Х. Н., А. Н. Веденин, Я. И. Яшин, д. Х. н., ООО «Интерлаб", Москва

УдК 543.54 Б.В.Немзер, К.X.H., University of Illinois, США yashin@interlab.ru

\begin{abstract}
Ягоды - один из важнейших источников антиоксидантов в питании человека. В кратком обзоре приведены сведения о содержании природных полифенолов - антиоксидантов в наиболее распространенных ягодах: клубника, клюква, брусника, черника, облепиха, калина, жимолость, вишня, голубика, черная смородина, арония. Обсуждаются состав и антиоксидантная активность ягод, которая определяется содержанием полифенолов-антиоксидантов. Приведены последние данные о публикациях с результатами исследований по влиянию регулярного потребления ягод на здоровье человека.
\end{abstract}

\section{ВВЕДЕНИЕ}

Ягоды - богатый источник природных антиоксидантов полифенолов. В наше время во многих странах они доступны круглогодично в свежем, замороженном, высушенном виде. Некоторые ягоды, ранее дикорастущие, сегодня культивируются на больших площадях: клюква, черника, голубика, облепиха. Более 20 лет назад начались исследования химического состава ягод, особенно их биоактивных соединений. Позднее ученые заинтересовались антиоксидантной активностью ягод и их отдельных компонентов. Опубликовано много общих обзорных статей о влиянии потребления ягод на здоровье человека [1-48], а также о биодоступности полифенолов - антиоксидантов из ягод. Созданы специализированные исследовательские институты по изучению состава и лечебных свойств ягод, организован научный журнал (J. Berry Research), регулярно раз в два года с 2005 года собираются международные симпозиумы - Berry Health Benefits Symposium (BHBS).

\section{СОДЕРЖАНИЕ АНТИОКСИДАНТОВ} \section{И АНТИОКСИДАНТНАЯ АКТИВНОСТЬ ЯГОД}

В табл. 1 приведены сведения о содержании флавоноидов, опубликованные в ряде обзоров и баз данных [49-53].

Больше всего в ягодах содержится антоцианидинов (цианидин, делфинидин, малвединин, пентунин) и флавонолов (кверцетин). Отметим, что кверцетин в разных количествах входит в состав практически всех ягод - это самый распространенный флавонол.
В табл. 2 приведены значения суммарного содержания антиоксидантов в соках из свежевыжатых ягод, определенных нами амперометрическим методом [50, 51], который очень селективен и идеально подходит для этой цели, поскольку другие соединения им не определяются. Из табл. 2 видно, что наибольшее содержание антиоксидантов в аронии и черной смородине.

В табл. 3 приведены значения антиоксидантной активности ягод, измеренные методом ORAC*. Они вошли в список 100 продуктов с наибольшей антиоксидантной активностью [54]. Единица измерения ORAC - микромоль тролоксэквивалента на 100 грамм (тролокс - водорастворимый аналог витамина Е), известны рекомендации по употреблению продуктов с индексом ORAC от 3000 до 5000 в день.

В табл. 4 приведено содержание очень важных антиоксидантов - проантоцианидинов [55], а также секоизоларицистенола дигликозида (secoisolariciresinol diglucosid - класс полифенольных антиоксидантов) в некоторых ягодах [56].

\footnotetext{
ORAC - англ. Oxygen radical absorbance capacity - флуориметрический метод определения абсорбционной емкости по отношению к кислородным радикалам. Метод основан на изменении интенсивности флуоресценции в зависимости от времени протекания реакции. Количественное измерение антиоксидантной активности проводится по определению площади между двумя кривыми показаний реакций-в отсутствие и в присутствии антиоксиданта (Мир измерений. 2012. № 1. С. 30-35).
} 
Табиица 1. Суммарное содержание фиавоноидов в ягодах [49]

\begin{tabular}{|c|c|c|}
\hline Название & $\begin{array}{l}\text { Суммарное содержание, } \\
\text { мг/100 г }\end{array}$ & $\begin{array}{l}\text { Флавоноиды, вносящие наибольший вклад, } \\
\text { мг/100 г }\end{array}$ \\
\hline Черная малина & 686,79 & Цианидин - 669,00 \\
\hline Бузина & 518,03 & Цианидин - 485,26 \\
\hline Черника (дикая) & 288,25 & Цианидин - 85,26; дельфинидин-97,59 \\
\hline Ирга & 180,78 & Цианидин-110,58; дельфинидин - 50,38 \\
\hline Черника (культ.) & 176,26 & Дельфинидин - 35,43; мальвинидин - 67,50; пентунидин - 31,53 \\
\hline Черная смородина & 170,29 & Цианидин - 62,46; дельфинидин - 89,62 \\
\hline Голубика (дикая) & 150,26 & Мальвидин - 57,16; дельфинидин - 37,59; цианидин - 19,35 \\
\hline Клюква & 130,78 & Цианидин - 46,43; неонидин - 49,16 \\
\hline Виноград (конкорд) & 125,35 & Дельфинидин - 70,62; цианидин - 23,76; пентунидин - 14,93 \\
\hline Можжевельник & 121,35 & Лутеолин - 69,65; кверцетин 46,61 \\
\hline Княженика & 101,5 & Цианидин - 88,30 \\
\hline Косточки винограда & 95,61 & (-) эпикатехин -93,31 \\
\hline Малина & 94,24 & Цианидин - 90,17 \\
\hline Красная смородина & 79,14 & Цианидин - 85,54 \\
\hline Брусника & 58,83 & Цианидин - 40,15 \\
\hline Aсаи & 53,64 & Цианидин - 53,64 \\
\hline Годжи & 31,20 & Кверцетин - 13,08; мирицетин - 11,40 \\
\hline Голубика (культ.) & 25,0 & Кверцетин - 17,70; мирицетин - 11,40 \\
\hline Клубника & 27,85 & Пеларгонидин - 24,85 \\
\hline Крыжовник & 13,72 & Цианидин $-8,73$ \\
\hline Морошка & 3,57 & Цианидин - 1,7 \\
\hline Белая смородина & 4,33 & Кверцетин - 2,68 \\
\hline Виноград белый & 6,80 & Эпикатехин - 1,7; (+) катехин - 3,73 \\
\hline Рябина & 7,40 & Кверцетин - 7,40 \\
\hline
\end{tabular}

\section{ХАРАКТЕРИСТИКА НАИБОЛЕЕ РАСПРОСТРАНЕННЫХ И ШИРОКО УПОТРЕБЛЯЕМЫХ ЯГОД}

\section{Клубника}

Клубника - одна из самых распространенных ягод в мире, особенно в США и европейских странах. Сортов клубники много $[26,34,58]$, ее свойства интенсивно исследуются. В работах $[12,28,29,44]$ определено содержание флавоноидов и антоцианинов, изучено влияние клубники на здоровье человека $[36,44]$, в том числе профилактическое действие против онкологических болезней [19, 34, 35, 57-60, 70]. Клубника обладает высокой пищевой ценностью, в ней содержится (г/100 г): белки - 0,43; общие липиды 0,11; углеводы - 9,13; пищевые волокна - 2,1; общий сахар 4,56. Витамины (в мг/100г): витамин С-41,2; витамин Е (альфа - токоферол) - 0,29; тиамин - 0,02; рибофлавин 0,037; ниацин - 0,46; фолиевая кислота - 17; витамин В12-1; витамин К - 2,2. Из каротиноидов больше всего в клубнике бета-каротина - 27 мг/100г, лютеина + зеаксантина 26 мг/100 г. Клубника обладает высокой антиоксидантной активностью за счет высокого содержания полифенолов антиоксидантов, среди которых антоцианины - 41\%, флаван-3-олы - 28\%, эллаготаннины - 14\%, коричные кислоты (конъюгированные) - 13\%, флавонолы - 3\%, эллаговая кислота (конъюгированная) - 1\% [35, 36]. В клубнике есть ценные микроэлементы (в мг/100г): $\mathrm{K}-148, \mathrm{Ca}-16, \mathrm{Mg}-11, \mathrm{P}-13$, $\mathrm{Fe}-0,75, \mathrm{Cu}-0,05$.

Методом ВЭЖХ-МС в клубнике идентифицированы:

- флаван-3-олы;

- флавонолы: кверцетин, кемпферол; 
Таблица 2. Суммарное содержание антиоксидантов (ССА) в ягодах $[50,51]$

\begin{tabular}{|l|r|}
\hline Название & ССА, \\
\hline Черная рябина (арония) & 800 \\
\hline Черная смородина & 765 \\
\hline Черная вишня & 572 \\
\hline Боярышник & 570 \\
\hline Шиповник & 530 \\
\hline Калина & 495 \\
\hline Черника & 406 \\
\hline Голубика & 335 \\
\hline Клюква & 270 \\
\hline Барбарис & 230 \\
\hline Черная черешня & 221 \\
\hline Лесная клубника (земляника) & 210 \\
\hline Красная смородина & 200 \\
\hline Рябина & 200 \\
\hline Малина & 171 \\
\hline Брусника & 143 \\
\hline Крыжовник & 46 \\
\hline Черный виноград & 40 \\
\hline Облепиха & \\
\hline & \\
\hline
\end{tabular}

- антоцианидины: цианидин, делфинидин, пелларгонидин, пеонидин, петунедин;

- антоцианины: цианидин-3-гликозид, пеларгонин3-гликозид, пеларгонидин-3-рутинозид, цианидин3-малонгликозид, пеларгонидин-3-малонгликозид и др.;

- проантоцианидины: проантоцианидин димер и проантоцианидин - тример;

- коричные кислоты коньюгированные;

- эллаготаннины и эллаговая кислоты.

Пищевая ценность клубники настолько высока, что ее относят к продуктам функционального питания [57]. За счет полифенолов - антиоксидантов клубника обладает многими лечебными действиями $[35,36]$. Потребление клубники снижает концентрацию внутриклеточных реакционных кислородных соединений; повышает активность антиоксидантных ферментов; успокаивает воспалительные процессы; уменьшает окислительный стресс; замедляет процессы старения; способствует заживлению язвы желудка; уменьшает окисление липидов желудка
Табпица 3. Ягоды, вошедшие в список 100 продуктов с максимальным значением ORAC [54]

\begin{tabular}{|l|r|}
\hline Название & $\begin{array}{l}\text { Значение ORAC, } \\
\text { мкмоль TE/ 100 г }\end{array}$ \\
\hline Acaи & 102700 \\
\hline Magni (порошок) & 75000 \\
\hline Маgni (сок ягоды) & 40000 \\
\hline Годжи & 25300 \\
\hline Клюква & 9584 \\
\hline Смородина черная & 7960 \\
\hline Голубика & 6552 \\
\hline Ежевика & 5347 \\
\hline Малина & 4882 \\
\hline Клубника & 3577 \\
\hline Красная смородина & 3387 \\
\hline Вишня & 3365 \\
\hline Крыжовник & 3277 \\
\hline & \\
\hline
\end{tabular}

и улучшает липидный профиль; ингибирует агрегацию тромбоцитов; улучшает эндотелиальные функции сосудов и увеличивает антиоксидантную емкость плазмы; снижает окисление липопротеинов низкой плотности, риски инфаркта миокарда и развития онкологических заболеваний.

\section{Клюква}

Клюква - богатый источник природных антиоксидантов, витаминов и микроэлементов. В промышленных масштабах ее выращивают в США, России, Канаде, Белоруссии, Польше и Скандинавских странах.

Омолаживающий эффект клюквы давно известен, его подтверждают исследования, согласно которым только эта ягода обладает большим набором антиоксидантов с регенерирующим эффектом. По исследованию химического состава и влиянию клюквы на здоровье человека вышло сотни научных статей и обзоров $[37,69]$. В одном из последних обобщены сведения из разных статей о ее химическом составе [69]. Приведем данные о содержании полифенолов в клюкве мг / 100 г:

- флаван-3-олы: (-) эпикатехин (7-33); (+) эпикатехин; (-) катехин; (+) катехин;

- проантоцианидины: проантоцианидин A2 (133-367) проантоцианидин В2;

- антоцианины, антоцианидины (13-171): пеонидин, цианидин, малвидин, дельфинидин, петунидин, пеларгонидин. 
Табиица 4. Суммарное содержание проантоцианидинов и лигнанов в ягодах

\begin{tabular}{|c|c|c|}
\hline Название & $\begin{array}{c}\text { Среднее из четы- } \\
\text { рех-восьми изме- } \\
\text { рений в мг / } 100 \text { г } \\
\text { (от веса свежего } \\
\text { продукта) [55] }\end{array}$ & $\begin{array}{r}\text { Содер- } \\
\text { жание } \\
\text { лигнанов, } \\
\text { мкг / г [56] }\end{array}$ \\
\hline Косточки винограда & $3532,3 \pm 105,8$ & - \\
\hline Арония & $663,7 \pm 47,7$ & - \\
\hline Клюква & $418,8 \pm 75,3$ & 15,1 \\
\hline Голубика (лесная) & $331,9 \pm 14,0$ & - \\
\hline Голубика (культвир.) & $179,8 \pm 50,8$ & - \\
\hline Черная смородина & $147,8 \pm 33,0$ & - \\
\hline Клубника & $145,0 \pm 24,9$ & 12,1 \\
\hline Виноград (зеленый) & $81,5 \pm 15,0$ & - \\
\hline Виноград (красный) & $61,0 \pm 12,3$ & - \\
\hline Малина & $30,2 \pm 23,4$ & - \\
\hline Черника & $27,0 \pm 17,5$ & 37,1 \\
\hline Marion berries & $8,9 \pm 0,1$ & - \\
\hline Вишня & $8,2 \pm 3,2$ & - \\
\hline Брусника & - & 15,1 \\
\hline Красная смородина & - & 1,6 \\
\hline
\end{tabular}

- гидроксибензойные кислоты (503-602): бензойная, п-гидроксибензойная, о-гидроксибензойная, 2, 4-дигидробензойная;

- гидроксикоричные кислоты (73-82): п-кумаровая, кофейная, феруловая, синаповая.

\section{Брусника}

Состав флавоноидов в бруснике определен методом ВэжХ-МС [38]: флаванолы-5,8\%, флавонолы-3,8\%, фенольные кислоты - 1,9\%, антоцианины - 1,5\%. Всего идентифицировано 39 фенольных соединений, семь из них в достаточно больших концентрациях. В экстрактах обнаружены кофейная, п-кумаровая, феруловая, хлорогеновая кислоты; проантоцианидины B1, B2 и А2, кверцетины, антоцианины производные пеонидина, петунидина, малвидина, делфинидина и цианидина и многие другие.

Потребление брусники защищает от окислительного стресса, предотвращает падение в сыворотке восстановленного глутатиона - естественного эндогенного антиоксиданта [38].

\section{Черника}

Превосходный источник природных антиоксидантов, обладающих многими лекарственными действиями [14, 67].
Последние исследования показали, что черника обладает высокой антиоксидантной активностью и уменьшает риск онкологических и сердечнососудистых заболеваний, оказывает противовоспалительное действие. Она содержит большое количество антоцианинов и других фенольных антиоксидантов, а также флавонолов, фенольных кислот, эллаговую кислоту, витамин С. Цианидин-3-о-глюкозид из черники обладает терапевтическим эффектом in vivo $u$ in vitro.

Содержание, мг/100 г: сумма фенолов - 4199 \pm 50 , флавоноиды - $160 \pm 12$, антоцианины - $1669 \pm 54$, цианидин-3-оглюкозид примерно $586 \pm 9$.

Методом ВЭЖХ-МС в чернике обнаружены разные полифенольные соединения, мг/100 г [53]:

- антоцианины: - цианидин-3-о-диокалилгликозид 3,57-19,34, цианидин-3-о-малонилгликозид 2,38-5,50, цианид-3-о-гликозид 85,21-190,82, цианид-3-о-рутинозид 1,34-13,82, цианид-3-о-ксилозид 4,6-17,81;

- флавонолы: (+) катехины 0,66-0,79, (-) эпикатехин 2,67-18,08, (-) эпигаллокатехин 0-0,36;

- процианидины: процианидин В1 димер - 0,23, процианидин В2 димер - 0,83, процианидин триммер0,06, проделфинидин В3-0,07;

- флавонолы: кверцетин-3-о-галактозид 1,2-8,04, кверцетин-3-о-глюкозид 0,0-6,0, кверцетин-3-о-гликозилксилозид 0,00-0,93, кверцетин-3-о-рутинозид 0,00-24,00, кверцетин-3-о-ксилозилглюкоронид 0,62-5,69;

- гидроксибензойные кислоты: 4-гидроксибензойная кислота 4-о-гликозид 0,5-2,10, эллаговая кислота 20,00-69,00, галловая кислота 2,00-9,00, прокатехиновая кислота-4-о-гликозид 0,20-0,60;

- гидроксикоричные кислоты: 3-кафеоилхинные 4,10-5,20, 3-ферулоилхинная 0,20-0,40, 3-п-кумароилхинная 0,20-0,50, 4-кафеоилхинная 0,10-0,10, 5-кафеоилхинная 0,00-0, 30, п-кумариновая 4-о-гликозид 0,20-0,40, кверцетин 1,27, феруловая кислота 2,3, п-кумаровая 0,60, ресвератрол 0,67.

\section{Облепиха}

Богатый источник полифенолов - антиоксидантов. Обладает лечебными свойствами и широко применяется как в традиционной, так и в народной медицине. В соке ягод содержится (в мг/л): витамин C - 1540, флавоноиды 1182, витамин E - 13,5 (как токоферолы, так и токотриенолы) и каротиноиды-7,3 (лютеин, зеаксантин, бета-криптоксантин, ликопин, бета-каротин, гамма-каротин, этерифицированные каротиноиды) [62].

Облепиха - источник других полезных компонентов, в том числе витамины - A, B1, B2, B5, B9, B12, D. В облепихе содержится богатый набор омега 3, 6, 9 кислот и редкой омега 7, причем в самых полезных комбинациях; олеиновая кислота 17\%, омега-3-альфа-линоленовая кислота - 34\%, 
омега-6 линолевая - 31\%. Фитостеролов 1,3-2\%, что в 4-20 раз больше, чем в соевом масле.

Природные антиоксиданты - полифенолы: галловая кислота, катехин, эпикатехин, кофейная кислота, п-кумариновая кислота, феруловая, рутин, кверцетин, изорампетин, кемпферол, изорампетин-3-о-рутинозид; изорампетин-3-о-гликозид; кверцетин-3-о-рутинозид; кверцетин-3-о-гликозид и др. Общее содержание 10-60 мг / 100 г (в основном флавонолы до 50 мг/100 г).

Микроэлементы (в мг/кг): железо-4,3; цинк-6,99; медь2,3; марганец - 3,65; никель - 0,53; фосфор - 0,36; кальций0,17; натрий-0,46; калий-19,78; магний - 0,9.

В облепихе (ягодах, побегах) обнаружен гормон серотонин. Кроме ягод природные антиоксиданты содержатся также в листьях и побегах (ветках) облепихи, причем в листьях их содержание значительно больше, чем в ягодах и побегах. В некоторых работах представлены результаты исследований, в которых изучали измения в содержании полифенолов - антиоксидантов в течение июня - сентября как в ягодах, так и в листьях и побегах.

Облепиха обладает разнообразными лечебными эффектами [62]: усиливает иммунитет, помогает при воспалительных процессах, сердечнососудистых заболеваниях, применяется при терапии кожных болезней, защищает печень от воздействия токсичных соединений, обладает антибактериальным, противовирусным действием. В традиционной китайской медицине облепиха применяется для лечения язв желудка, легочных заболеваний.

\section{Калина}

В работе [63] определен состав биологически активных соединений плодов калины обыкновенной из областей средней полосы РФ (11 образцов). Калина широко применяется как в традиционной, так и в народной медицине. Государственная фармакокопея РФ содержит статью по приготовлению плодов калины, а в Государственный реестр РФ лекарственных средств включены два препарата из нее. Плоды калины и продукты на ее основе внесены в Реестр продукции, прошедшей государственную регистрацию в Роспотребнадзоре в качестве сырья для БАДов.

Плоды калины обладают противовоспалительным, антирадикальным, гипотензивным, спазмолитическим, антибактериальным, диуретическим действиями.

В [63] полифенолы (флавоноиды, антоцианины, фенольные кислоты, проантоцианидины и др.) определяли методом ВЭЖХ-ТОГ-МС и ВЭЖХ-МС / МС. Суммарное содержание (мг/100 г): полифенолы (в пересчете на галловую кислоту) 403,0-733,9; олигомерные проантоцианидины 201,0-528,0, сумма антоцианинов 10,0-26,0. Отдельно определяли хлорогеновую кислоту, ее концентрация колебалась в пределах 250,0-580,0.
Методом ВЭЖХ-МС в калине идентифицировано 10 антоцианинов, в основном производные цианидина: цианидин-3-арабиновый глюкозид (17,2-41,5\%), цианидин-3глюкозид (33,9-77,6\%) и цианидин-3-рутиназид (1,5-20.6\%), встречаются цианидин-3-ксилозил-рутинозид и цианидин-3глюкозид. Всего плоды калины содержат от четырех до восьми антоцианинов (глюкозиды антоцианидинов). Содержание олигомерных проантоцианидинов в калине (201,0-528 мг/100 мг) практически такое же, как в клюкве (примерно 400 мг / 100 г) и голубике (около 500 мг / 100 г).

По содержанию аскорбиновой кислоты (от 40 до 92,0 мг/100 г) калина превосходит клюкву, бруснику, чернику, голубику, кизил и уступает только черной смородине.

Антирадикальная активность (DPPH-тест) в пределах 577-968,0 мг ТЭ/100 г, по способности связывать свободные радикалы калина не уступает другим ягодам с высокой биологической активностью (клюква, брусника, черная смородина, черника, голубика, жимолость, кизил).

\section{Жимолость}

Сырьевая база жимолости - Россия, Китай, Япония. В жимолости идентифицировано 262 вещества, основные - хлорогеновая кислота, цианидин-3-гликозид, цианидин-3-рутинозид.

В работе [64] содержание флавоноидов определено колориметрическим методом с образованием комплексов, поглощающих при 510 нм, мг/100 г: катехин 153-214; цианидин-3-гликозид 4629,1-8505,6, аскорбиновая кислота 232-325; сумма антоцианов-897,4-1168,3.

\section{Вишня}

Антиоксидантную активность разных сортов вишни изучали методами ABTS, CURAC и FRAP $[65,66]$, результаты приведены в табл. 5.

Определены антоцианины в 11 сортах темных и светлых сладких вишнях методом ВЭЖХ и ГХ [66]. Во всех темноокрашенных вишнях были обнаружены 3-рутинозид и 3-гликозид цианидина как основные антоцианины. Общее содержание антоцианинов находится в пределах 82-297 мг / 100 г в темных и от 2 до 41 мг / 100 г для светлоокрашенных сортов. Основные бесцветные полифенолы - неохлорогенная кислота (24-128 мг/100 г) и п-кумароилхинная кислота (23131 мг / 100 г), их количество в разных сортах колеблется очень сильно. Отдельные цианидины, мг/100 г: цианидин -3-гликозид 4,2-44,1, цианидин-3-рутинозид 1,37-243,9, пеонидин3-гликозид 0,3-1,13, пелоргонидин-3-рутинозид 0,27-3,21, пеонидин-3-рутинозид 1,74-16,60. В обзоре [48] обсуждается влияние вишни на здоровье человека.

\section{Голубика}

Голубика считается полезной ягодой, поскольку содержит полифенолы, флавоноиды и фенольные кислоты (галловая, 
Таблица 5. Антиоксидантная активность, содержание фиавоноидов и полифенолов в разных сортах вишни

\begin{tabular}{|l|c|c|r|r|r|}
\hline $\begin{array}{l}\text { Coрта } \\
\text { вишни }\end{array}$ & $\begin{array}{r}\text { Антиоксидантная актив- } \\
\text { ность, ммоль/100г [66] }\end{array}$ & $\begin{array}{r}\text { Сумма } \\
\text { флавоноидов, } \\
\text { ммль/100г [25] }\end{array}$ & $\begin{array}{r}\text { Солифенолов, } \\
\text { мг/100г [25] }\end{array}$ \\
\hline & ABTS & CuRAC & FRAP \\
\hline Sour cherry & 17,8 & 29,7 & 7,6 & 420,5 & 3371,1 \\
\hline Laurel & 28,4 & 46,9 & 13,3 & 952,5 & 3129,2 \\
\hline Cornelien & 50,8 & 76,3 & 22,3 & 477,3 & 4918 \\
\hline
\end{tabular}

п-гидрокибензойная, кофейная, п-кумаровая, феруловая, эллаговая) [67]. Некоторые сорта голубики содержат высокую концентрацию кислот, мг / 100 г: галловой до 258,9, феруловой 16,97 и эллаговой в пределах 0,75-6,65.

\section{Арония}

В черноплодной рябине много антиоксидантов, состав флавоноидов определен методом ВЭЖХ-МС [68]. Арония содержит флавонолов - агликонов 71 мг на 100 г (свежего сока), идентифицированы флавонолы - производные с сахарным остатком: кверцетин-3-гликозид, кверцетин-3-галактозид, кверцетин-3-рутинозид более 7 мг/100г, цианидин3-галактозид 315 мг /100г, цианидин-3-гликозид 10 мг/100г, цианидин-3-арабинозид 146 мг / 100г, цианидин-3-ксилозид 10 мг/100г, неохлорогеновая кислота 123 мг/100г, хлорогеновая кислота 61 мг / 100 г. В табл. 6 приведен химический состав черноплодной рябины, отмечается ее эффективноть в профиликтике рака молочной железы.

\section{Черная смородина}

Одна из самых полезных ягод благодаря богатому и уникальному содержанию витаминов, антиоксидантов и микроэлементов. Химический состав и антиоксидантная активность ягод, листьев, сока черной смородины определяли в ряде работ $[2,73-75,79]$. Суммарное содержание в черной смородине составило, мг / 100 мл [72]: полифенолов 580,4 0 0,36 (стандарт - галловая кислота), флавоноидов 84,6 0,7, антоцианинов 116,1 0 0,59.

Методом ВЭЖХ-МС идентифицированы и определены некоторые антоцианины $[80,81]$ (в мг/100 мл): делфинидин-3-о-глюкозид 22,3 1,86, делфинидин-3-о-рутинозид $57,95 \pm 2,31$, цианидин-3-о-гликозид 9,9 1,79, цианидин-3о-рутинозид 50,6 1,63.

Обнаружены катехины: эпигаллокатехин галлат, эпигаллокатехин, эпикатехингаллат, эпикатехин. Причем больше всего эпигаллокатехингаллата - 10-50\% от всей фракции экстракта черной смородины (аналогично катехинам зеленого чая).

Основные витамины, содержащиеся в черной смородине (в мг / 100 г) [73]: витамин C - 200, витамин В1 (тиамин) -0,03, витамин В2 (рибофлавин) - 0,04, витамин В5 (пантеновая кислота) - 0,04, витамин В6 (пиридоксин), витамин Е - 0,7, витамин Н (биотин) - 2,4, витамин РР (неациновый эквивалент) - 0,4. Витамин РР - 0,3 мг, витамин К - 30 мкг, витамин В9 (фолиевая кислота) - 5-7,7 мкг.

Состав микроэлементов (в мг/100 г): $\mathrm{Ca}-36, \mathrm{Mg}-31, \mathrm{Na}-32, \mathrm{~K}-350, \mathrm{P}-33$, $\mathrm{S}$ - 2. Отметим высокое содержание Mg и К, которые полезны для сердечнососудистой системы. Микроэлементы (в мкг / 100 г): иод - 1, медь - 130, марганец - 0,18, фтор - 17, молибден - 24, бор - 55, кобальт - 4, железо - 1,3 мг, цинк-0,13. Очень важно присутствие редких микроэлементов иода, фтора и бора. Идентифицированы также метилкверцетин, кверцетин, кофейная и п-кумаровая

Табпица 6. Химический состав черноплодной рябины [101]

\begin{tabular}{|c|c|}
\hline Вещества & Концентрации \\
\hline Глюкоза & 66-176г/кг \\
\hline Пищевая клетчатка & $56 г / \mathrm{K} \Gamma$ \\
\hline Жиры & $0,14 \%$ \\
\hline Белки & $0,7 \%$ \\
\hline Витамин С & $13-270 \mathrm{Mг} / \mathrm{Kг}$ \\
\hline Фолаты & $200 \mathrm{MKг} / \mathrm{Kг}$ \\
\hline Витамин В1 & $180 \mathrm{MKг} / \mathrm{Kг}$ \\
\hline Витамин В2 & $200 \mathrm{MKг} \mathrm{/} \mathrm{Кг}$ \\
\hline Витамин В6 & $280 \mathrm{MKг} / \mathrm{K \Gamma}$ \\
\hline Ниацин & $3000 \mathrm{MKг} / \mathrm{K} \Gamma$ \\
\hline Пантотеновая кислота & $2750 \mathrm{M} \mathrm{Кг} \mathrm{/} \mathrm{Кг}$ \\
\hline Токоферолы & $7,1 \mathrm{Mr} / \mathrm{kг}$ \\
\hline Витамин К & $242 \mathrm{M} \mathrm{Kг} \mathrm{/} \mathrm{кг}$ \\
\hline Каротиноиды & $48,6 \mathrm{Mr} / \mathrm{Kr}$ \\
\hline $\mathrm{Na}$ & $26 \mathrm{Mr} / \mathrm{Kr}$ \\
\hline K & $2180 \mathrm{Mr} / \mathrm{Kг}$ \\
\hline $\mathrm{Ca}$ & $322 \mathrm{Mг} / \mathrm{kг}$ \\
\hline $\mathrm{Mg}$ & $162 \mathrm{Mг} / \mathrm{Kг}$ \\
\hline $\mathrm{Fe}$ & $9,3 \mathrm{Mr} / \mathrm{Kr}$ \\
\hline $\mathrm{Zn}$ & $2,1\ulcorner/ \mathrm{K} \Gamma$ \\
\hline Лимонная кислота & $13,1 г / \mathrm{K} \Gamma$ \\
\hline Полифенольные соединения & 2010-6902 мг/100 г \\
\hline
\end{tabular}


кислоты. В аромате черной смородины обнаружено более 150 летучих соединений, в т. ч. альфа-терпинен, гамма-терпинен, 2-гексаналь, альфа -пинен и др. Плоды черной смородины широко применяются в народной медицине как мочегонное, потогонное и противовоспалительное средство.

Концентрация антиоксидантов в черной смородине зависит от сорта, месте выращивания и погодных условий [78]. Например, состав и антиоксидантная активность сока черной смородины, производимой в Германии, Польше, Англии и Финляндии различаются в три раза [79].

\section{ВЛИЯНИЕ ПОТРЕБЛЕНИЯ ЯГОД НА ЗДОРОВЬЕ ЧЕЛОВЕКА}

В табл. 7 обобщены сведения о влиянии потребления ягод на здоровье человека. Публикации о влиянии на здоровье отдельных ягод: вишни [48], клюквы [27, 37], лесной клубники [24], черной малины [18], клубники [44]. Продолжается поиск ягод с высокой антиоксидантной активностью. Находки последних лет: ягоды асаи из Южной Америки [54], годжи из Тибета [98], женьшеня [99].

\section{ЗАКЛЮЧЕНИЕ}

В обзоре приведены сведения о химическом составе ягод, содержании в них флавоноидов и фенольных кислот $[12,26,28,68,73]$, в частности, в [28] и [29] определено содержание флавоноидов в 25 и 19 видов ягод соответственно, а также содержание антоцианинов $[39,44,66]$. Измерена антиоксидантная активность клубники [12], черники [16], вишни [25], голубики [31], аронии и облепихи [32], ежевики и черники [69], черной смородины, ежевики и малины [74] и др.

Приведенные многочисленные данные о ягодах доказывают их высокую пищевую ценность, благодаря содержанию микронутриентов: витаминов, микроэлементов и полифенолов - антиоксидантов. Ягоды рекомендовано включать в состав функционального, здорового и полноценного питания, а также для профилактики различных болезней. Очень важно исследовать влияние потребления сочетания разных ягод и продуктов из них на здоровье человека.

\section{ЛИТЕРАТУРA / REFERENCES}

1. Berries and Cancer Prevention. Eds. Stoner G. D., Seeram N. P. Part 3. Springer. New York. 2011.

2. Basu A., Rhone M., Lyons T.J. Berries: emerging impact on cardiovascular health // Nutr.Res. 2010. V.68.p. 168-177.

3. Joseph S.V., Edirishingne I., Burton-Freeman B. M. Berries antiinflammatory effects in humans // J. Agric.Food Chem. 2014. V. 62. p. 38863903.

4. Yang B., Kortesniemi M. Clinical evidence on potential health benefits of berries. // Current opinion Food Sci. 2015. V. 2. p. 36-42.

5. Nile S. H., Park S.W. Edible berries: bioactive components and their effect on human health // Nutrition. 2014. V. 30. p. 134-144.

6. Rodrigues-Mateos A., Heiss C., Borges G., Crozier A. Berry polyphenols and cardiovascular health. // J. Agric. Food Chem. 2013. V. 62. p. 3842-3851.
Таблица 7. Публикации о влиянии потребления ягод на здоровье человека

\begin{tabular}{|c|c|}
\hline Виды заболеваний & Ссылка \\
\hline $\begin{array}{l}\text { Влияние потребления ягод на здоровье } \\
\text { человека. Обзоры общего характера }\end{array}$ & $\begin{array}{l}4,5,10,20,27 \\
40,44,45,47, \\
82-85\end{array}$ \\
\hline Сердечно-сосудистые заболевания & 2,6 \\
\hline Онкологические заболевания & $\begin{array}{l}1,18,19,21 \\
22,41,100\end{array}$ \\
\hline Диабет & 17 \\
\hline Нейродегенаративные заболевания & 33 \\
\hline Инфекции мочевыводящих путей & $69,88-90$ \\
\hline $\begin{array}{l}\text { Повышение антиоксидантного статуса } \\
\text { человека }\end{array}$ & 59,70 \\
\hline Остеопороз & 71 \\
\hline Воспалительные заболевания & 3 \\
\hline $\begin{array}{l}\text { Ухудшение памяти и умственных способ- } \\
\text { ностей }\end{array}$ & $8,42,43$ \\
\hline Ухудшение мозгового кровообращения & 7 \\
\hline Метаболический синдром & $9,14,24$ \\
\hline Болезни пожилого возраста & 40 \\
\hline Геликобактер пилори & 86,87 \\
\hline Периодонтит & 92,93 \\
\hline Кариес & 94 \\
\hline Инфекционные болезни & 95 \\
\hline Окислительный стресс & 97,99 \\
\hline
\end{tabular}

7. Miller M.G., Shukitt-Hole B. Berry fruit enhances beneficial signaling in the brain // J. Agric. Food Chem. 2012. v. 60. p. 5709-5715.

8. Krikorian R., Shidler M. D., Nash T. A. et al. Blueberry supplementation improves memory in older adults // J. Agric. Food Chem. 2010. V. 58 p. $3996-4000$.

9. Lehtonen H. M., Suomela J. P., Tahvonen R. et al. Berry meals and risk factors associated with metabolic syndroms. // Eur. J. Clin. Nutr. 2010 V. 64. p. 614-621.

10. Manganoris G.A., Goulas V., Vicente A.R., Terry L. A. Berry antioxidants: small fruits providing large benefits. Review. // J. Sci. Food Agric. 2014. V. 94. p. 825-833.

11. Rao A.V., Snyder D.M. Raspberries and human health. A Review. // J. Agric.Food Chem. 2010. V. 58. p. 3871-3883.

12. Wang S. Y., Lewers K. S. Antioxidant capacity and flavonoids content in wild strawberries // J. Am. Soc. Hortic Sci. 2007. v. 132. p. 629-637.

13. Konic-Ristic A., Sovicin K., Zdumic G. et al. Biological activity and chemical composition of different berry juces // Food Chem. 2011 v. 125 p. 1412-1417.

14. Basu A., Lyons T. J. Strawberries, blueberries and cranberries in the metabolic syndrome: clinical perspectives. // J. Agric Food Chem. 2012. v. 60. p. 5687-5692.

15. Morita M., Naito Y., Yoshikawa T., Niki E. Antioxidant capacity of blueberry extracts // J. Berry Res. 2017. V7. P. 1-9. 
16. Kosinska-Cognazzo A., Weber B., Chablais R. et al. Bioactive compound profile and antioxidant activity of fruits from six goji cultivars cultivated in Switzerland // J. Berry Res. 2017. v. 7. p. 43-59

17. Edirisimgne I., Burton-Freeman B. Anti-diabetic actions of berry polyphenols-review on proposed mechanism of action // J. Berry Res. 2016. v. 6. p. 37-250

18. Kresty L., Mollery S. R., Stoner G.D. Black raspberry in cancer clinical trials-post, present and future // J. Berry Res.2016 v. 6. p. 251-261.

19. Forbes-Hernandes T.Y., Gasparrini M., Afrin S., Mazzoni L. Reboredo P., Giampieri F. A comparative study on cytotoxic effects of strawberry extract on different cellular models. // J. Berry Res. 2016 V. 6. p. $263-275$

20. Seeram N.P., Shakitt-Hole B. Advances in berry research. The sixth biennial berry health benefits symposium // J. Berry Res.2016. v. 6 P. 93-95.

21. Agil F., Jeyabalon J., Kousar H., Munayala R., Singh I. P., Gupta R. Lung cancer ingibitory activity of dietary berries and berry polyphenols. // J. Berry Res. 2016 v. 6. p. 105-114.

22. Weh K., Aiyer H.S., Howell A. B., Kresty L. A. Cranberry proanthocyanidins modute reactive oxygen species in Barrett $\mathrm{S}$ and esofagel adenocarcinoma cell lines // J. Berry Res. 2006. V 6. P. 125136.

23. Prior R. L., Sintara M., Chang T. Multi-radical (ORACmrs) antioxidant capacity of selected berries and effects of food processing // J. Berry Res.2016. v. 6. p. 159-173.

24. Klimis-Zacas D., Vendrame S., Kristo A.S. Wild blueberries attenuate risk factors of the metabolic syndrome. // J. Berry Res. 2016 v. 6. p. 225256

25. Pissard A., Lateur M., Magein H. et al. Determination of total phenolic compound content and antioxidant activity of cherry species and cultivars. J. Berry Res. 2016. v. 6. p. 81-91.

26. Arisa M.T., Martinez-Ferri E. Effects of harvest time on functional compounds and fruit antioxidant capacity in ten strawberry cultivars. // J. Berry Res.2015 v. 5.p. 71-80/27.

27. Battino M., Beekwilder J., Denoyes-Rothan B. Bioactive compounds in berries relevant to human health // Nutr.Rev. 2009 v. 67.p. 145-150.

28. Häkkinen S. H., Kärenlampi S. O., Heinonen I. M., Mykkänen H. M. Törrönen A. R. Content of the Flavonols Quercetin, Myricetin, and Kaempferol in 25 Edible Berries // Journal of Agricultural and Food Chemistry.1999. V. 47. № 6. P. 2274-2279.

29. Häkkinen S., Heinonen M., Kärenlampi S., Mykkänen H., Ruuskanen J., Törrönen R. Screening of selected flavonoids and phenolic acids in 19 berries // Food Research International. 1999. V. 32. № 5. P. 345-353.

30. Namiesnik J. et.al. Antioxidant activities and bioactive components in some berries // Eur. Food Res. Technol. 2013. V.237. P. 819-829.

31. Wang C.Y., Wang S.Y., Chen C. Increasing antioxidant activity and reducing decay of blueberries by essential oils // J. Agric. Food Chem. 2008. V.56. P. 3587-3592.

32. Li W., Hydamaka A.W., Lowry L. Trust Beta Comparison of antioxidant capacity and phenolic compounds of berries, chokecherry and seabuckthorn // Central European Journal of Biology. 2009. V. 4. Issue 4 P. 499-506.

33. Giacalone M., Di Sacco F., Traupe I., Topini R., Forfori F., Giunta F. Antioxidant and neuroprotective properties of blueberry polyphenols: a critical review // Nutr.Neurosci., 2011. V.14. P. 119-125.

34. Giampieri F., Alvarez-Suarez J., Tulipani S., Battino M. Phytochemica profiling of strawberry fruits, and bioactive compounds from the same selected cultivar in human plasma during a medium-term consumption study // BMC Proceedings 2012. V.6 (Suppl 3). P. 5

35. Giampieri F., Tulipani S., Alvarez-Suarez J., Quiles J., Mezzetti B., Battino $\mathbf{M}$. The strawberry: Composition, nutritional quality and impact on human health // Nutrition. 2012. V.28. P. 9-19.

36. Giampieri F., Alvarez-Suarez J. M.; Battino M. Strawberry and Human Health: Effects beyond Antioxidant Activity // J. Agric. Food Chem. 2014 V. 62. P. 3867-3876.

37. Blumberg J. B., Camesano T. A., Cassidy A., Kris-Etherton P., Howell A., Manach C., Ostertag L. M., Sies H., Skulas-Ray A., Vita J. A. Cranberries and Their Bioactive Constituents in Human Health // Advances in Nutrition: An International Review Journal. 2013. V. 4. № 6. P. 618-632.
38. Mane C., Loonis M., Juhel C., Dufour C., Malien-Aubert C. Food Grade Lingonberry Extract: Polyphenolic Composition and In Vivo Protective Effect against Oxidative Stress // J. Agric. Food Chem. 2011. V.59. P. 33303339.

39. Jing P., Giusti M.M. Contribution of Berry Anthocyanins to Their Chemopreventive Properties // Berries and Cancer Prevention/Seeram N. P., Stoner G. D. Springer New York, 2011. - C. 3-40.

40. Paredes-López O., Cervantes-Ceja M. L., Vigna-Pérez M., HernándezPérez T. Berries: improving human health and healthy aging, and promoting quality life - a review // Plant Foods Hum Nutr. 2010. V. 65. N. 3. P. 299-308.

41. Folmer F., Basavaraju U., Jaspars M., Hold G., El-Omar E., Dicato M., Diederich M. Anticancer effects of bioactive berry compounds // Phytochemistry Reviews 2014. V.13. Issue 1. P. 295-322.

42. Devore E. E., Kang J.H., Breteler M. M., Grodstein F. Dietary intakes of berries and flavonoids in relation to cognitive decline // Ann. Neurol. 2012. V.72. P. 135-143.

43. Cherniack E.P. A berry thought-provoking idea: the potential role of plant polyphenols in the treatment of age-related cognitive disorders // Br.J. Nutr., 2012. P. 1-7.

44. Giampieri F, Tulipani S, Alvarez-Suarez J, Quiles J, Mezzetti B, Battino M. The strawberry: Composition, nutritional quality and impact on human health // Nutrition. 2012. V.28. P. 9-19.

45. Nile S. H., Se Won Park. Edible berries: Bioactive components and their effect on human health // Nutrition. 2014. V. 30. Issue 2. P. 134-144.

46. Zafra-Stone S., Yasmin T., Bagchi M., Chatterjee A., Vinson J. A., Bagchi D. Berry anthocyanins as novel antioxidants in human health and disease prevention // Mol. Nutr. Food Res. 2007. V.51. P. 675-83.

47. Seeram N.P. Berries and human health: research highlights from the Fifth Biennial Berry Health Benefits Symposium // J Agric Food Chem. 2014. V.62. № 18. P. 3839-3841.

48. Letitia M. McCune, Chieri Kubota, Nicole R. Stendell-Hollis, Cynthia A. Thomson Cherries and Health: A Review // Critical Reviews in Food Science and Nutrition. 2010. V. 51. Iss. 1. P. 1-12.

49. USDA Database for the flavonoid content of selected foods. 2009

50. Yashin Ya.l., Nemzer B.V., Ryzhnev V.Yu., Yashin A.Ya., Chernousova N. I. and Fedina P. A. Creation of a Databank for Content of antioxidants in food products by an amperometric method. // Molecules. 2010. v. 15. р. 7450-7466.

51. Яшин Я. И., Рыжнев В. Ю., Яшин А. Я., Черноусова Н. И. Природные антиоксиданты. Содержание в пищевых продуктах и их влияние на здоровье и старение человека. М., ТрансЛит, 2009, 192 с. Yashin Ya. I., Ryzhnev V. Yu., Yashin A. Ya., Chernousova N. I. Natural antioxidants. Content in food products and their impact on human health and aging. M., TransLit Publ., 2009, 192 p.

52. Carlsen M.H., Halvorsen B. L., Holte K., Bøhn S. K., Dragland S., Sampson L., Willey C., Senoo H., Umezono Y., Sanada C., Barikmo I., Berhe N., Willett W.C., Phillips K. M., Jacobs D. R. Jr., Blomhoff R. The total antioxidant content of more than 3100 foods, beverages, spices, herbs and supplements used worldwide // Nutr. J. 2010, v. 9, p. 1-11.

53. Pérez-Jiménez J., Neveu V., Vos F., Scalbert A. Systematic analysis of the content of 502 polyphenols in 452 foods and beverages: an application of the Phenol-Explorer database // J. Agric. Food Chem. 2010. 58. P. 4959-4969.

54. Top 100 High ORAC Value Antioxidant Foods 2014 K. Jorgustin.

55. Gu L., Kelm M. A., Hammerstone J. F., Beecher G., Holden J., Haytowitz D., Gebhardt S. and Prior R. L. Concentrations of proanthocyanidins in common foods and estimations of normal consumption // Journal of Nutrition. 2004. V.134. P. 613-617.

56. Dhaval Patel, Jitendra Vaghasiya, S. S. Pancholi, Arindam Paul. Therapeutic Potential of Secoisolariciresinol Diglucoside: A Plant Lignan // International Journal of Pharmaceutical Sciences and Drug Research 2012. V.4. № .1. P. 15-18.

57. Basu A., Nguyen A., Nancy M. Betts, Timothy J. Lyons Strawberry As a Functional Food: An Evidence-Based Review // Critical Reviews in Food Science and Nutrition. 2014. V. 54. P. 790-806.

58. Kosinska A., Sascha Diering, Denis Prim, Julien Heritier, Wilfried Andlauer Phenolic compounds profile of strawberry fruits of Charlotte cultivar // Journal of Berry Research 2013. V. 3. P. 15-23. 
59. Azzini E., Intorre F., Vitaglione P., Napolitano A., Foddai M. S. Durazzo A., Fumagalli A., Catasta G., Rossi L., Venneria E., Testa M. F., Raguzzini A., Palomba L., Fogliano V., Maiani G. Absorption of strawberry phytochemicals and antioxidant status changes in humans // J. Berry Res. 2010. V.1. P. 81-89.

60. Schwieterman M. L., Colquhoun T. A., Jaworski E. A., Bartoshuk L. M. Gilbert J. L., et al. Strawberry Flavor: Diverse Chemical Compositions a Seasonal Influence, and Effects on Sensory Perception // PLoS ONE2014. V. 9. № 2. P. 1-12.

61. Cho B. O., Ryu H.W., Jin C.H., Choi D.S., Kang S.Y., Kim D.S. Byun M.-W., Jeong I.Y. Blackberry Extract Attenuates Oxidative Stress through Up-regulation of Nrf2-Dependent Antioxidant Enzymes in Carbon Tetrachloride-Treated Rats // Journal of Agricultural and Food Chemistry. 2011. V.59. P. 11442-11448.

62. Christaki E. Hippophae rhamnoides L. (Sea Buckthorn): a potential source of nutraceuticals // Food Public Health. 2012 V.2. P. 69-72.

63. Перова И.Б., Жогова А.А., Черкашин А.В., Эллер К.И. Раменская Г.В., Самылина И. А. Биологически активные вещества плодов калины обыкновенной // Химико - фарм. журнал. 2014 T. 48. № 5. C. 32-39.

Perova I.B., Zhogova A.A., Cherkashin A.V., Eller K.I., Ramenskaya G.V., Samylina I. A. Biologically active substances of viburnum fruit. Khimiko - farm. zhurnal. 2014. T.48. № 5. p. 32-39.

64. Макарова И. В., Э. В. Мусифуллина, Дмитриева А. Н., Соболев Г.И., Азаров О.И. Исследование антиоксидантных свойств жимолости. Пищевая промышленность. 2012. № 2. с. 56-60.

Makarova I.V., E. V. Musifullina, Dmitrieva A. N., Sobolev G.I., Azarov O.I. The study of the antioxidant properties of honeysuckle // Food industry. 2012. № 2. P. 56-60.

65. Capanoglu E., Boyacioglu D., de Vos R.C.H., Hall R. D., Beekwilder J. Procyanidins in fruit from Sour cherry (Prunus cerasus) differ strongly in chainlength from those in Laurel cherry (Prunus lauracerasus) and Cornelian cherry (Cornus mas) // J. Berry Res. 2011. 1. P. 137-146.

66. Gao L., Mazza G. Characterization, quantition and distribution of anthocyanins and colorless phenolics in sweet cherries // Journal of Agricultural and Food Chemistry. 1995. V.3. P. 343-346.

67. Sellappan S., Akoh C.C., Krewer G. Phenolic Compounds and Antioxidant Capacity of Georgia-Grown Blueberries and Blackberries // Journal of Agricultural and Food Chemistry. 2002. V.50. P. 2432-2438.

68. Slimestad R., Toskangerpoll K., Nateland H. S., Johannessen T., and Giske N. H. Flavonoids from black chokeberries, Aronia melanocarpa // J. Food Comp. Anal. 2005. V.18. P. 61-68

69. Micali S., Isgro G., Bianchi G., Miceli N., Calapai G., Navarra M. Cranberry and Recurrent Cystitis: More than Marketing? // Critical Reviews in Food Science and Nutrition. 2014 v. 54, Iss.8. P. 1063-75.

70. Romandini S. et.al. Effects of an acute strawberry (Fragaria $\times$ ananassa) consumption on the plasma antioxidant status of healthy subjects // Journal of Berry Research 2013. V.3. № 3. P. 169-179.

71. Patrice A. Hubert, Sang Gil Lee, Sun-Kyeong Lee, Ock K. Chun Dietary Polyphenols, Berries, and Age-Related Bone Loss: A Review Based on Human, Animal, and Cell Studies // Antioxidants 2014. V.3. P. 144158.

72. Butnariu M. Detection of the polyphenolic components in Ribes nigrum L. // Annals of Agricultural and Environmental Medicine. 2014. V. 21. No 1 P. 11-14

73. Tabart J., Kevers C., Evers D., Dommes J. Ascorbic acid, phenolic acid, flavonoid, and carotenoid profiles of selected extracts from Ribes nigrum. // J Agric Food Chem. 2011. V.59. P. 4763-4770.

74. Kucharska A.Z., Sokol - Letowska A., Gabrielska J., Bakowska Barczok A. et. al. Antioxidant properties of polyphenolic extracts from chokeberry, black currant, blackberry, raspberry fruits // Annals universitatis M. Curic-Sklodowska. 2011. V.24. № 3. P. 183-188.

75. Vagiri M., Conner S., Stewart D., Andersson S. C., Verrall S., Johansson E., Rumpunen K. Phenolic compounds in blackcurrant (Ribes nigrum L.) leaves relative to leaf position and harvest date // Food Chemistry. 2015. V. 172. P. 135-142.

76. Gopalan A., Reuben S.C., Ahmed S., Darvesh A. S., Hohmann J., Bishayee A. The health benefits of blackcurrants // Food \& Function 2012. V. 3. № 8. P. 795-809.
77. Lister C., Wilson P., Sutton K., \& Morrison, S. Understanding the health benefits of blackcurrants // Acta Horticulturae. 2002. V.2. P. 443450

78. Heng J., Yang B., Ruusunen V., Laaksonen O., Tahvonen R., Hellsten J., Kallio H. Compositional Differences of Phenolic Compounds between Black Currant (Ribes nigrum L.) Cultivars and Their Response to Latitude and Weather Conditions // Journal of Agricultural and Food Chemistry. 2012. V. 60. № 26. P. 6581-6593.

79. Mattila P. H., Hellstrum J., McDougall G., Dobson G., Pihlava J.-M., Tiirikka T., et al. Polyphenol and vitamin C contents in European commercial blackcurrant juice products // Food Chemistry, 2011. V.127. P. 1216-1223.

80. Diaconeasa Z., Loredana Leopold, Dumitrița Rugină, Huseyin Ayvaz, Carmen Socaciu Antiproliferative and Antioxidant Properties of Anthocyanin Rich Extracts from Blueberry and Blackcurrant Juice // Int. J. Mol. Sci. 2015. V.16. P. 2352-2365.

81. Rubinskiene M., Jasutiene I., Venskutonis P.R., Viskelis P. HPLC Determination of the Composition and Stability of Blackcurrant Anthocyanins // Journal of Chromatographic Science. 2005. V. 43. № 9. P. 478-482.

82. Govers C., Kasikci M.B., van der Sluis A.A., Mes J.J. Review of the health effects of berries and their phytochemicals on the digestive and immune systems. // Nutrition Reviews. 2018. V.76. p. 29-48.

83. Olas B. Berry phenolic antioxidants implications for human health // Front Pharmacol. 2018. V.9. p. 78.

84. Yeung A.W.K., Tzvetkov N.T., Zengin G. et al The berries on the top // J. Berry Research. 2019. DOI: https://doi.org/10.3233/JBR-180357.

85. Castro D., Teodoro A. Anticancer properties of bioactive compound of berry fruits- a review // Br. J. Med Med. Res. 2015. V.6. P. 771-794.

86. Burger O., Weiss E., Sharon N. et al. Inhibition of Helicobacter pylori adhesion to human gastric mucus by a high-molecular-weight constituent of cranberry juice. // Crit. Rev. Food Sci. Nutr. 2002. v. 42. P. 279-284.

87. Zhang L., Ma J., Pan K.E. Efficacy of cranberry juice on Helicobacter pylori infection a double-blind, randomized placebo-controlled trial. // Helicobacter. 2005. V.10. P. 139-145.

88. Jepson R., Mihalijevic L., Craig J. Cranberries for preventing urinary tract infections // Cochrane Database Syst. Rev. 2004. CD001321.

89. Afshar K., Stothers L., Scott H., MacNeily A. E. Cranberry juice for the prevention of pediatric urinary tract infection-randomized controlled trial. // J. Urol. 2012. v. 188. P. 1584-1587.

90. Guay D. R. Cranberry and urinary tract infections // Drugs. 2009. v. 69 p. 775-807.

91. Gettman M.T., Ogan K., Brinkley I.J.et al. Effect of cranberry juice consumption on urinary stone risk factors // J. Urol. 2005. V 174. P. 590594.

92. Feghali K., Feldman M., La V.D., Santos J. Grenier D. Cranberry proanthocyanidins- natural weapons against periodontal diseases. // J. Agric. Food Chem. 2012. V.60. p. 5728-5735.

93. Bodet C., Grenier D., Chandad F. et al. Potential oral health benefits of cranberry. // Crit. Rev. Food Sci. Nutr. 2008. V.48. p. 672-680.

94. Philip N., Walsh L.J. Cranberry polyphenols-natural weapons against dental caries // Denistry J. 2019. V.7.P.20.

95. Shmuely H., Ofek I., Weiss E. I. et al. Cranberry components for the therapy of infection diseases. // Curr. Opin. Biotech. 2012. V.23. p. 148152.

96. Huang P. J., Wen Y., Yearsley M. et al. An immunological perspective for preventing cancer with berries. // J. Berry Res. 2018. V.8. p. 163-175.

97. Forbes-Hernandez T.Y. et al. Strawberry extract attenuates oxidative stress in 3T3-LI cells. // J. Berry Res. 2018. V.8. p. 193-203.

98. Skenderidis P., Lampakis D., Giavasis I. et al. Chemical properties, fatty-acid composition and antioxidant activity of Goji berry fruits. // Antioxidants. 2019. V.8. P.60.

99. Parikh M., Ray P., Yu L. et al. Ginseng berry extract rich in phenolic compounds attenuates oxidative stress. // Int.J.Molec. Sci. 2019. V. 20. P. 983.

100. Scaer C. et al. Berries and other natural products in pancreatic cancer chemoprevention in human clinical trials. // J. Berry Res.2017. v. 7. P.147-161.

101. B. Olas. Role of black choken berries in breast cancer: a focus on antioxidant activity in V. Preedy ed. Cancer: oxidative stress and dietary antioxidants Elsevier. Amsterdam. 2014. P. 151-157. 


\section{СНЕЖНЫЙ НАНОГЕНЕРАТОР}

Трибоэлектрический эффект известен тысячи лет и заключается в том, что один материал приобретает электрический заряд после контакта с другим. Ученые разрабатывают трибоэлектрические наногенераторы (ТЭН), чтобы в результате трения одного материала о другой накапливать энергию природных явлений (океанские волны, дождевые капли, ветер) в виде электричества. Одним из природных источников электрических зарядов являются снежинки во время снегопада. Электризация снега основана на упорядочивании электрических диполей молекул воды при кристаллизации, и до недавнего времени это явление оставалось природным феноменом.

Американские исследователи разработали недорогой и компактный ТЭН, который собирает снежное электричество. Устройство, работает в одноэлектродном режиме и использует контактную электризацию (снег падает на поверхность
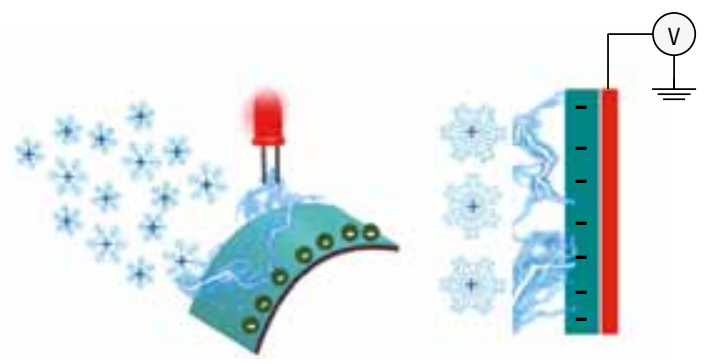

прибора) и электростатическую индукцию (снежинки скользят вдоль поверхности). Ученые протестировали различные материалы, от алюминиевой фольги до тефлона, чтобы найти трибоэлектрик, который производит максимальный разряд при контакте со снегом. В результате был выбран силикон. ТЭН изготовили методом 3-D печати: на пластиковую основу нанесли электропроводящий полимер (поли (3,4-этилендиокситиофен) / поли (стиренсульфонат) с добавкой диметил сульфата для повышения проводимости) в качестве электрода и трибоэлектрификационный слой УФ-отверждаемых силиконовых чернил. Контакт снега и силикона производит разряд, который устройство преобразует в электрический ток. Снежный ТЭН, подключенный к резистору на 50 мОм, обеспечивает плотность выходной мощности до 0,2 мВт / м², плотность тока 40 мкА / м $^{2}$ а выходное напряжение достигает $8 \mathrm{~V}$.

Разработчики предлагают множество вариантов использования снежного ТЭНа. Устройство может автономно работать в отдаленных районах как генератор энергии или часть метеостанции, показывая силу ветра, количество и направление падающего снега. Интегрировав снежный ТЭН в солнечные панели, можно обеспечить непрерывное энергоснабжение во время снегопада. Датчик можно закрепить на одежде и преобразовывать его сигналы в информацию о движении человека. Это может стать началом нового поколения устройств для отслеживания характеристик бега, ходьбы или прыжков в зимних видах спорта.

Nano Energy, 2019.

DOI: 10.1016/j.nanoen.2019.03.032

\section{МИНИСТЕРСТВО НАУКИ И ВЫСШЕГО ОБРАЗОВАНИЯ РОССИЙСКОЙ ФЕАЕРАЦИИ РОССИЙСКАЯ АКААЕМИЯ НАУК НАУЧНЫЙ СОВЕТ РАН ПО АНААИТИЧЕСКОЙ ХИМИИ МОСКОВСКИЙ ГОСУААРСТВЕННЫЙ УНИВЕРСИТЕТ ИМ. М.В. АОМОНОСОВА ИНСТИТУТ СПЕКТРОСКОПИИ РАН КУБАНСКИЙ ГОСУААРСТВЕННЫЙ УНИВЕРСИТЕТ}

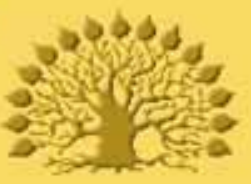

\section{УВАЖАЕМЫЕ КОЛЛЕГИ!}

Приглашаем Вас принять участие в работе III Всероссийской конференции по аналитической спектроскопии с международным участием.

\section{ОРГАНИЗАЦИОННЫЙ КОМИТЕТ:}

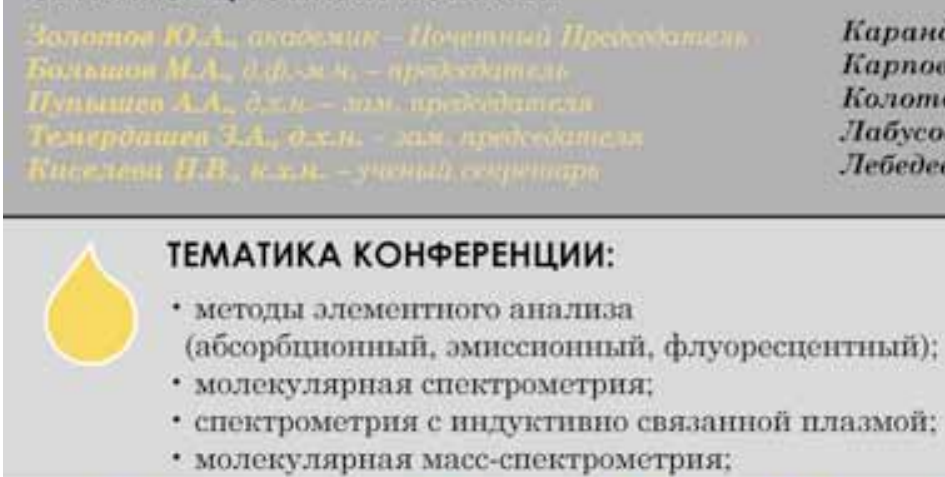

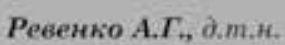
Сапрыкин А.Н., д.х.н. Спиваков Б.Я., чен,-корр. РАH

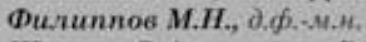
ШІпигуи O.A., т.љ.-корр. РАН Шmbeкos C.H., д.x.H.
- ренттеновская спектрометрия;

- лазеры в спектрометрнческом анализе;

- приборн, автоматиаачия, комтьютеризация;

- метрология спектрометрическом аналиаа;

- отбоор н подтотовка проб в спектрометрическом анализе; - анализ реальных образцов. 